\title{
Absorption kinetics of some carbohydrates in conscious pigs
}

\section{Quantitative aspects}

\author{
BY A. A. RERAT, P. VAISSADE AND P. VAUGELADE \\ Laboratoire de Physiologie de la Nutrition, Centre National de Recherches Zootechniques, \\ INRA, 78350 Jouy-en-Josas, France
}

(Received 1 November 1983 - Accepted 15 December 1983)

1. Concentrations of reducing sugars, glucose, fructose and lactic acid in blood obtained from arterial and portal catheters were measured together with the portal hepatic blood flow-rate for periods of $8-24 \mathrm{~h}$ in twenty-six unanaesthetized pigs (mean body-weight $51 \mathrm{~kg}$ ). The animals received experimental meals containing different amounts $(100-1600 \mathrm{~g})$ of different sugars (glucose fifteen meals, sucrose twenty-four meals, lactose fourteen meals, maize starch nineteen meals) together with a protein-mineral-vitamin mixture $(150 \mathrm{~g}) 6-8 \mathrm{~d}$ after implantation of the catheters and an electromagnetic flow probe.

2. Because the portal blood flow pattern did not differ between test meals, net absorption followed the same trends as for porto-arterial concentration differences (Rérat et al. 1984). Apart from lactose, the amounts of reducing sugars appearing in the portal vein correlated with the intake of the test meal, but the absorption pattern was different for each sugar. The appearance of reducing sugars was faster and earlier after intake of glucose than after sucrose and the same was the case for sucrose relative to maize starch. The differences between the three carbohydrates tended to increase with the level of intake.

3. With a test meal containing $1 \mathrm{~kg}$ carbohydrate, i.e. a normal meal in a $50 \mathrm{~kg}$ pig, digestion of sucrose and maize starch was not finished $8 \mathrm{~h}$ after the meal since only 60 and $52 \%$ respectively of their hydrolysis products were recovered in the portal blood. In the case of lactose, the amounts of reducing sugars appearing in the portal blood were always very small and constant (113-118 $\mathrm{g}$ within $8 \mathrm{~h}$ ) whatever the level of intake, i.e. 30 and $15 \%$ of their hydrolysis products for intakes of 400 and $800 \mathrm{~g}$ respectively.

4. Depending on the carbohydrate ingested, the uptake of glucose by the gut cell wall ranged from 14 to $21 \mathrm{~g} / \mathrm{h}$ and the production of lactic acid from $2 \cdot 5$ to $3 \cdot 5 \mathrm{~g} / \mathrm{h}$.

In our previous paper (Rérat et al. 1984) it was shown how the type and level of carbohydrate intake led to various ranges of porto-arterial differences in the concentration of reducing sugars, accounting for the appearance of carbohydrate-hydrolysis products in the animal. However, these ranges only indicate trends of differences between digestion and absorption rates of the various hydrolysis products since the blood flow-rate of the gut may change according to the over-all composition of the diets used. Therefore, in addition to qualitative aspects of the appearance of nutrients in the portal vein after feeding the four carbohydrates (glucose, sucrose, lactose and maize starch), we studied quantitative aspects of digestion and absorption by measuring the absorption kinetics of these products using a technique based on the determination of blood flow-rate in the portal vein combined with the measurement of the porto-arterial concentration differences of nutrients (Rérat et al. 1980).

\section{EXPERIMENTAL}

\section{Animals, diet, feeding conditions and measurements}

Twenty-six castrated male pigs of mean body-weight $51 \mathrm{~kg}$ were prepared as described in the previous paper (Rérat et al. 1984). On the day of the experiment, after a fasting period of $20 \mathrm{~h}$, the animals received in one daily meal at 09.00 hours a given amount of between 100 and $1600 \mathrm{~g}$ of the carbohydrate studied (maize starch nineteen meals, lactose fourteen meals, sucrose twenty-four meals, glucose fifteen meals) in addition to a concentrate diet $(150 \mathrm{~g})$ supplying a protein-vitamin-mineral mixture (Rérat et al. 1984). The distribution 
of intake levels for each sugar is shown in Fig. 2 (see p. 523). In some cases, the same animal was offered the same amount of the same experimental meal twice in order to test variability between meals. These replications were made once with glucose $(400 \mathrm{~g})$, twice with sucrose $(400 \mathrm{~g})$, once with sucrose $(800 \mathrm{~g})$, once with sucrose $(1200 \mathrm{~g})$ and once with lactose $(500 \mathrm{~g})$. Techniques of sampling and chemical determinations are described in the previous paper (Rérat et al. 1984).

\section{Statistical analyses}

Statistical analyses (Snedecor \& Cochran, 1967) involved the same techniques as in the previous paper (Rérat et al. 1984); also included were correlation coefficients $(r)$ and comparisons of two slopes ( $F$ test).

When the same meal was offered to an animal on two occasions, the mean result was used rather than the individual values in order to prevent values for this animal from prevailing over those of other animals receiving the same test meal only once.

\section{Definitions and calculations}

The method used is based on quantitative determination of the rise (Rérat, 1971) in the intestinal blood level of nutrients after the meal by measurement of the porto-arterial differences $\left(C_{p}-C_{a}\right)$ of nutrient concentrations in the gut blood at any moment after the meal and by multiplication of these differences by the corresponding flow-rate $(D)$ and by the duration of digestion according to the formulas:

$$
\begin{gathered}
q=\left(C_{p}-C_{a}\right) D d t \\
Q=\sum_{t_{0}}^{t_{1}} q,
\end{gathered}
$$

where $q$ is the quantity absorbed during the short time $d t(5 \mathrm{~min})$, during which the factors could be considered as constant; $C_{p}$ is the portal concentration; $C_{a}$ the arterial concentration; $D$ the flow in the portal vein, and $Q$ the quantity absorbed during the post-prandial period between times $t_{0}$ and $t_{1}$. This measurement does not involve the total absorption, but only the net influx of nutrients in the portal blood, as some nutrients coming from the intestinal lumen or from the arterial blood may be metabolized or catabolized in the gastrointestinal wall. For an ingested nutrient, the recorded values correspond to the absorption in excess relative to the gut tissue metabolism when the porto-arterial difference is positive, or to the gut tissue metabolism in excess relative to the absorption when the porto-arterial difference is negative. On the other hand, the synthesis of a non-ingested nutrient by the gastrointestinal wall can be measured in this way (Rérat et al. 1980).

Because the reducing power of galactose towards ferricyanide is $30 \%$ lower than that of glucose, it is necessary to correct the quantity of reducing sugars appearing in the portal blood after intake of lactose. The quantity of glucose absorbed (Glu) determined from the difference between portal and arterial blood glucose concentrations multiplied by the portal blood flow is subtracted from the amount of total reducing sugars absorbed $(S)$ determined according to the same principle. The difference $S-G l u$, representing mostly galactose plus some reducing substances other than sugars, is then multiplied by the factor 1.33 which takes into account the lower reducing power of galactose towards ferricyanide. This new quantity $(G a l)$ is added to the quantity of glucose $(G l u)$ and the sum $(G a l+G l u)$ gives the corrected quantity of sugars appearing $(S R)$. However, this rather over-estimates the quantity of galactose appearing because the calculation involves some reducing substances other than sugars. 
Table 1. Portal blood flow-rate over a post-prandial period of $8 \mathrm{~h}$ after intake of various carbohydrates

(Mean values with their standard errors)

\begin{tabular}{|c|c|c|c|c|c|c|c|}
\hline \multirow[b]{3}{*}{ Carbohydrate } & \multirow[b]{3}{*}{$A$} & \multicolumn{4}{|c|}{ Intake level } & \multirow{2}{*}{\multicolumn{2}{|c|}{$\begin{array}{c}\text { Mean flow-rate } \\
(\mathrm{ml} / \mathrm{min} \text { per } \mathrm{kg} \text { live } \mathrm{wt})\end{array}$}} \\
\hline & & \multicolumn{2}{|c|}{ (g) } & \multicolumn{2}{|c|}{$(\mathrm{ml} / \mathrm{min})$} & & \\
\hline & & Mean & SEM & Mean & SEM & Mean & SEM \\
\hline Glucose & 12 & 409 & 53 & 2066 & 138 & $42 \cdot 5$ & $2 \cdot 3$ \\
\hline Sucrose & 11 & 530 & 53 & 2040 & 124 & $41 \cdot 9$ & $3 \cdot 1$ \\
\hline Lactose & 11 & 554 & 60 & 1973 & 135 & $40 \cdot 0$ & $2 \cdot 8$ \\
\hline Maize starch & 13 & 662 & 95 & 2014 & 64 & $41 \cdot 7$ & $2 \cdot 2$ \\
\hline
\end{tabular}

$A$, no. of animals.

\section{RESULTS}

Variations in the portal blood flow-rate during the post-prandial period

With regard to the flow-rate there was no statistical difference between levels of intake for each carbohydrate and for all carbohydrates together so that is was possible to calculate mean flow-rates for each carbohydrate (all levels of intake together) during the post-prandial period (Table 1). There was no significant difference in the mean flow-rate during the post-prandial period with regard to carbohydrate. The mean variation in the portal blood flow-rate with time is described for each carbohydrate in Fig. $1(a, b, c, d)$. The expression of results as mean values reduced the individual variations since maxima and minima values from day-to-day did not necessarily occur at the same time of the day in the same animal, or in different animals. The mean pattern of the blood flow-rate during the post-prandial period did not seem to show the same trends for all carbohydrates ingested although differences for each time were not significant (see SEM).

Quantitative absorption kinetics of carbohydrate-hydrolysis products

Absorption balance of reducing sugars during a post-prandial period of $8 h$. Results concerning the mean net amounts of reducing substances appearing in the animal during a postprandial period of $8 \mathrm{~h}$ are reported in Table 2; their statistical significances at a given time after the meal are given in Table 3.

The amounts of reducing sugars appearing in the portal vein varied according to the carbohydrate ingested. Except for lactose, they increased simultaneously with the ingestion level and the differences from one level to another for a given carbohydrate appeared very early and were larger than the differences between carbohydrates. At the lowest level of intake $(400 \mathrm{~g})$ there were no statistical differences between glucose, sucrose and maize starch according to the time elapsed after the meal, but the differences were significant between each of the three sugars and lactose (except for maize starch $4 \mathrm{~h}$ after the meal). At the $800 \mathrm{~g}$ level of intake, there were no significant differences between glucose and sucrose according to the time elapsed after the meal; the differences were significant between maize starch and glucose from 2 to $8 \mathrm{~h}$ and between maize starch and sucrose from 4 to $8 \mathrm{~h}$. The differences between lactose and the other three carbohydrates were always highly significant. At higher levels, the quantities of reducing sugars absorbed after ingestion of sucrose were significantly greater than with maize starch. It was of interest to note the amounts of reducing sugars which did not appear in the portal blood during the first $8 \mathrm{~h}$ of digestion. These mean quantities increased with the level of intake, indicating that, at the highest levels, 


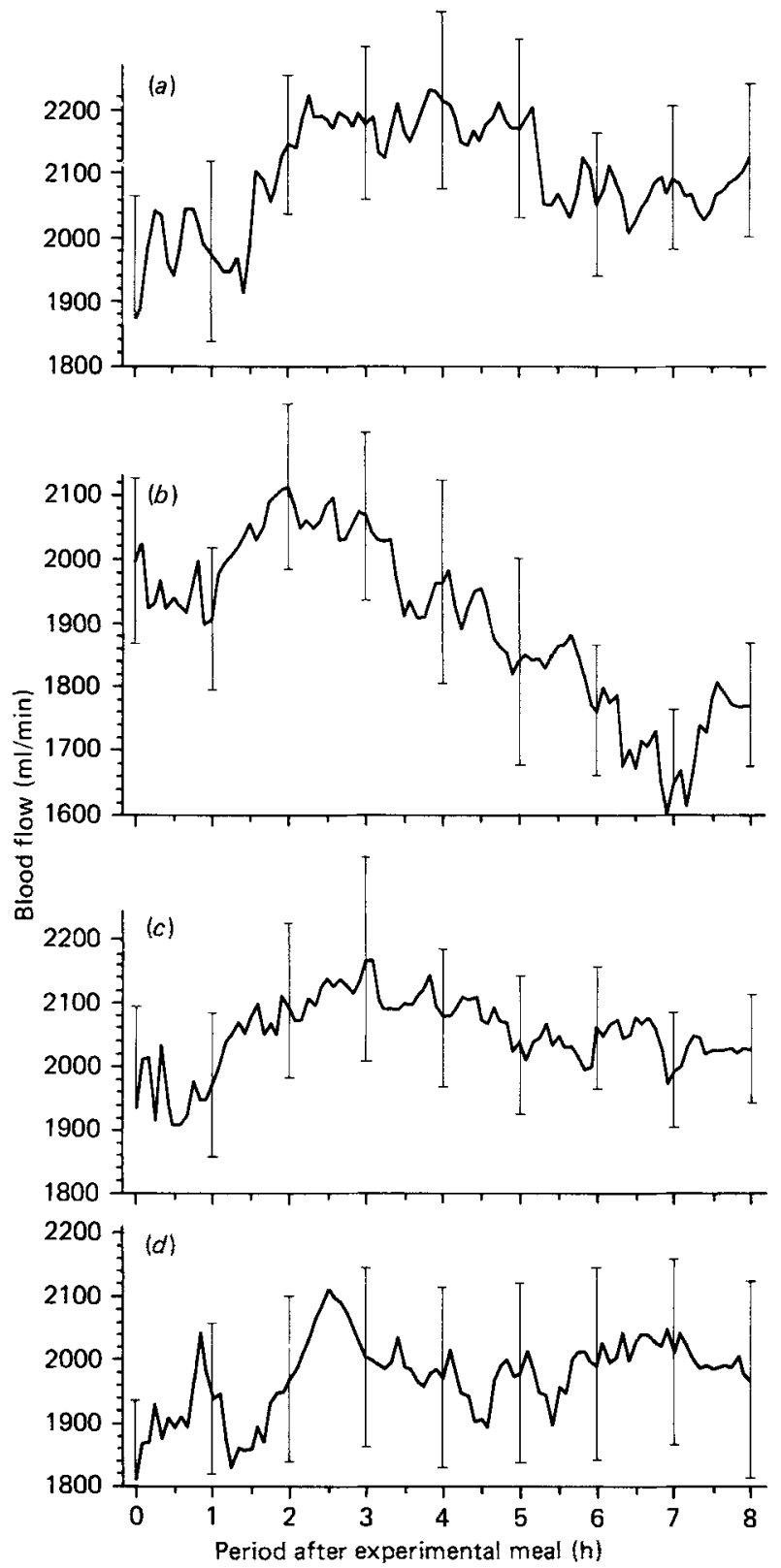

Fig. 1. Daily variations in the mean portal blood flow-rate $(\mathrm{ml} / \mathrm{min})$ during the post-prandial period after carbohydrate intake. (a) Glucose (no. of animals $(A) 12$; mean intake $(m i) 409 \mathrm{~g}$ (SEM 53)); $(b)$ sucrose ( $A$ 11, mi $530 \mathrm{~g}$ (SEM 53)); (c) maize starch (A 13, mi $662 \mathrm{~g}$ (SEM 95)); (d) lactose (A 11, mi $554 \mathrm{~g}$ (SEM $60)$ ). Each meal was supplied with $150 \mathrm{~g}$ protein-cellulose-vitamin-mineral mixture (Rérat et al. 1984). The last non-experimental meal was given $20 \mathrm{~h}$ before the experimental meal. Standard errors are represented by vertical bars. 
Table 2. Cumulated amounts* $(g)$ of reducing sugars appearing in the portal vein during a post-prandial period of $8 \mathrm{~h}$ after intake of different carbohydrates

(Mean values with their standard errors)

\begin{tabular}{|c|c|c|c|c|c|c|c|c|c|c|c|c|}
\hline \multirow{2}{*}{\multicolumn{2}{|c|}{$\begin{array}{c}\text { Intake of } \\
\text { carbohydrates } \\
(\mathrm{g}) \dagger\end{array}$}} & \multirow[b]{3}{*}{ Carbohydrate } & \multirow[b]{3}{*}{$N$} & \multirow[b]{3}{*}{$A$} & \multicolumn{8}{|c|}{ Period after the meal (h) } \\
\hline & & & & & \multicolumn{2}{|c|}{2} & \multicolumn{2}{|c|}{4} & \multicolumn{2}{|c|}{6} & \multicolumn{2}{|c|}{8} \\
\hline $\begin{array}{c}\text { Fresh } \\
\text { wt }\end{array}$ & $\begin{array}{c}\text { Dry } \\
\text { wt }\end{array}$ & & & & Mean & SEM & Mean & SEM & Mean & SEM & Mean & SEM \\
\hline 400 & 365 & Glucose & 6 & 5 & 72 & 9 & 176 & 36 & 231 & 52 & 245 & 48 \\
\hline 400 & 400 & Sucrose & 11 & 9 & 80 & 10 & 167 & 21 & 226 & 34 & 254 & 40 \\
\hline 400 & 396 & Lactose & 5 & 5 & 46 & 3 & 90 & 7 & 115 & 7 & 134 & 9 \\
\hline 400 & 350 & Maize starch & 7 & 7 & 70 & 9 & 131 & 25 & 176 & 29 & 214 & 30 \\
\hline 800 & 731 & Glucose & 4 & 4 & 157 & 21 & 345 & 43 & 483 & 36 & 592 & 27 \\
\hline 800 & 800 & Sucrose & 6 & 5 & 123 & 17 & 296 & 24 & 444 & 25 & 531 & 32 \\
\hline 800 & 792 & Lactose & 4 & 4 & 36 & 10 & 70 & 20 & 99 & 28 & 127 & 35 \\
\hline 800 & 699 & Maize starch & 5 & 5 & 102 & 10 & 220 & 33 & 302 & 49 & 361 & 55 \\
\hline 1200 & 1200 & Sucrose & 3 & 2 & 175 & & 374 & & 558 & & 658 & \\
\hline 1200 & 1049 & Maize starch $\ddagger$ & 2 & 2 & 147 & & 314 & & 459 & & 553 & \\
\hline 1600 & 1398 & Maize starch & 2 & 2 & 164 & & 374 & & 564 & & 710 & \\
\hline
\end{tabular}

$N$, no. of test meals of a specific carbohydrate at a given dose; $A$, no. of animals; $N-A$, replications of the same meal for the same animal (no more than two replications for one animal).

- Measured from the 5 min values obtained by continuous measurement of porto-arterial differences and of portal blood flow-rate.

$\dagger$ Dry wt: fresh wt, glucose 0.914 , sucrose 0.999 , lactose 0.991 , maize starch 0.874 .

$\ddagger$ One animal ingested $1200 \mathrm{~g}$ maize starch, the other $1150 \mathrm{~g}$.

Table 3. Significance of the difference between amounts $(g)$ of reducing sugars appearing in the portal vein (see Table 2) at a given time after the meal during a post-prandial period of $8 \mathrm{~h}$ after intake of some carbohydrates

\begin{tabular}{|c|c|c|c|c|c|c|c|c|c|}
\hline \multirow{2}{*}{\multicolumn{2}{|c|}{$\begin{array}{l}\text { Intake of carbohydrates } \\
\text { (g fresh matter)... } \\
\text { Period after the } \\
\text { meal (h)... }\end{array}$}} & \multicolumn{4}{|c|}{400} & \multicolumn{4}{|c|}{800} \\
\hline & & 2 & 4 & 6 & 8 & 2 & 4 & 6 & 8 \\
\hline \multicolumn{10}{|c|}{ Difference between: } \\
\hline Glu and: & $\begin{array}{l}\text { Su } \\
\text { St } \\
\text { La }\end{array}$ & $\begin{array}{c}\text { NS } \\
\text { NS } \\
* *\end{array}$ & $\begin{array}{l}\text { NS } \\
\text { NS } \\
* *\end{array}$ & $\begin{array}{c}\text { NS } \\
\text { NS } \\
*\end{array}$ & $\begin{array}{c}\text { NS } \\
\text { NS } \\
{ }^{*}\end{array}$ & $\begin{array}{c}\text { NS } \\
* \\
* *\end{array}$ & $\begin{array}{c}\text { NS } \\
* *\end{array}$ & $\begin{array}{r}\text { NS } \\
* \\
* *\end{array}$ & $\begin{array}{l}\text { NS } \\
* * \\
* *\end{array}$ \\
\hline Su and: & $\begin{array}{l}\text { St } \\
\mathrm{La}\end{array}$ & $\begin{array}{c}\text { NS } \\
*\end{array}$ & $\underset{*}{\text { NS }}$ & $\underset{*}{N S}$ & $\underset{*}{\text { NS }}$ & $\underset{* *}{N S}$ & $\stackrel{*}{*}$ & $\begin{array}{r}* \\
* *\end{array}$ & $\stackrel{\bullet}{* *}$ \\
\hline St and: & $\mathrm{La}$ & $*$ & NS & $*$ & $*$ & $* *$ & $* *$ & $* *$ & ** \\
\hline
\end{tabular}

Glu, glucose; Su, sucrose; St, maize starch; La, lactose; NS, not significant.

Statistical analysis ( $t$ test corrected for an unequal number of values, comparison being made at a given time after the meal): ${ }^{*} 0.01<P<0.05, * * P<0.01$. 


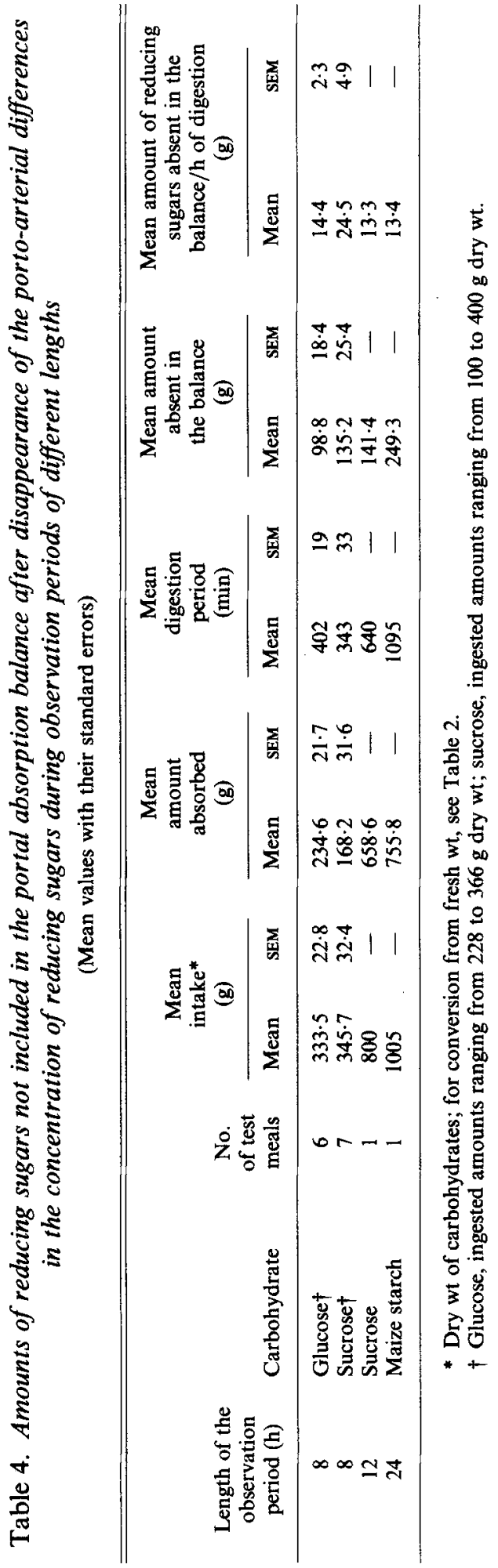




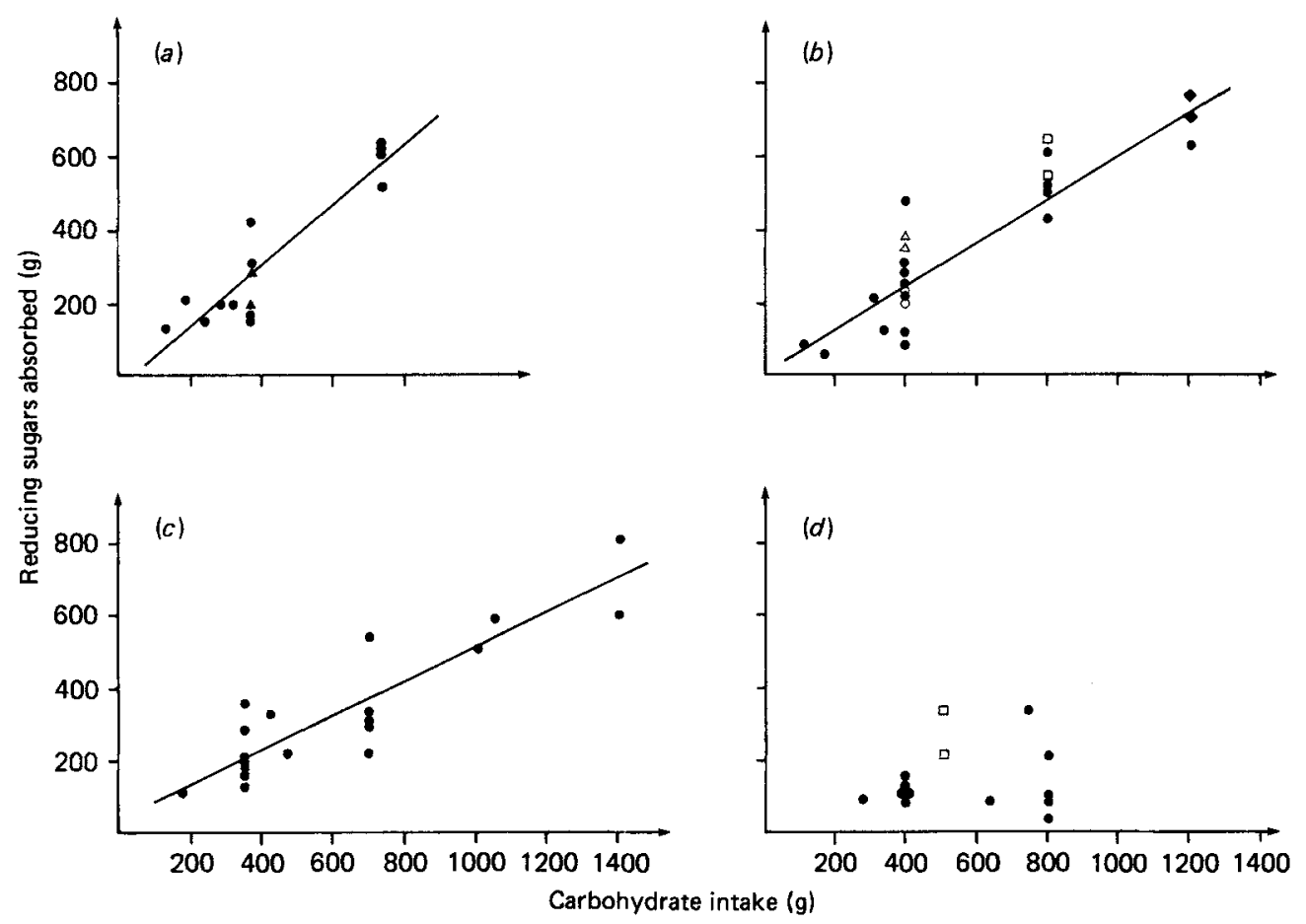

Fig. 2. Relationships between the amounts of reducing sugars absorbed and the amount of carbohydrate ingested. $A$, no. of animals.
(a) Glucose
$(y=0.83 x-27.39 ; r 0.91(P<0.01), A 14)$.
(b) Sucrose
$(y=0.59 x+13.33 ; r 0.89(P<0.01), A 20)$.
(c) Maize starch
(d) Lactose
$(y=0.48 x+41.13 ; r 0.89(P<0.01), A 19)$.
( $r 0 \cdot 09$, not significant, $A$ 13).

Each meal was supplied with $150 \mathrm{~g}$ protein concentrate (Rérat et al. 1984). The last non-experimental meal was given $20 \mathrm{~h}$ before the experimental meal. $\triangle, \square, O, \square, \Delta$, Replicated meals in the same animal; these were taken into account as means in the calculation of the regressions.

the digestion was not finished. They were approximately the same (from 120 to $146 \mathrm{~g}$ ) at the $400 \mathrm{~g}$ intake levels of glucose, sucrose and maize starch. These results should be discussed when considering the utilization of sugars by the gut wall. To estimate the amounts which might have been taken up by the cell wall, only experiments in which the porto-arterial differences have disappeared before the end of the observation period, i.e. when digestion is apparently finished, should be taken into account (Table 4). In these conditions, the values recorded in $8 \mathrm{~h}(14.4 \mathrm{~g} / \mathrm{h})$ for small levels of glucose intake are much lower than those recorded $(24.5 \mathrm{~g} / \mathrm{h})$ with small amounts of sucrose. The reasons for this difference require more accurate determination.

The regression of the cumulated amounts of reducing sugars appearing in the portal vein during the post-prandial period studied $(8 \mathrm{~h})$ relative to the amounts consumed was calculated (Fig. 2) with the particular aim of considering all the individual levels of ingestion. Except for lactose, these relationships were very close and could be described by first order equations. However, these equations showed marked differences depending on the carbohydrate ingested, since the slopes of the lines were significantly different, from glucose to sucrose and from sucrose to maize starch, for cumulated amounts absorbed during $8 \mathrm{~h}$. Thus, in terms of percentage of portal net absorption during $8 \mathrm{~h}$, calculated from these 
Table 5. Amounts $(g)$ of glucose appearing* in the portal blood during a post-prandial period of $8 \mathrm{~h}$ after intake of different carbohydrates

(No. of meals and animals, as for Table 2)

\begin{tabular}{|c|c|c|c|c|c|}
\hline \multirow{2}{*}{$\begin{array}{c}\text { Fresh wt } \\
\text { intake of } \\
\text { carbohydrates } \\
\text { (g) }\end{array}$} & \multirow[b]{2}{*}{ Carbohydrates } & \multicolumn{4}{|c|}{$\begin{array}{l}\text { Amount (g) of glucose appearing } \\
\text { in the portal vein }\end{array}$} \\
\hline & & $2 \dagger$ & $4 \dagger$ & $6 \dagger$ & $8 \dagger$ \\
\hline 400 & Glucose & $65 \cdot 2$ & $156 \cdot 3$ & $195 \cdot 4$ & $207 \cdot 5$ \\
\hline 400 & Sucrose & $48 \cdot 4$ & $96 \cdot 2$ & $123 \cdot 6$ & $137 \cdot 0$ \\
\hline 400 & Lactose & $25 \cdot 7$ & $50 \cdot 5$ & $67 \cdot 2$ & $77 \cdot 4$ \\
\hline 400 & Maize starch & $61 \cdot 7$ & $110 \cdot 7$ & $148 \cdot 0$ & $183 \cdot 2$ \\
\hline 800 & Glucose & $133 \cdot 2$ & $304 \cdot 6$ & 413.9 & $509 \cdot 7$ \\
\hline 800 & Sucrose & $69 \cdot 2$ & $162 \cdot 1$ & $237 \cdot 1$ & $283 \cdot 5$ \\
\hline 800 & Lactose & 20.5 & $39 \cdot 6$ & $57 \cdot 4$ & $73 \cdot 5$ \\
\hline 800 & Maize starch & $88 \cdot 7$ & $185 \cdot 9$ & $254 \cdot 0$ & $309 \cdot 0$ \\
\hline \multirow[t]{2}{*}{1200} & Sucrose & $106 \cdot 4$ & $212 \cdot 7$ & $301 \cdot 0$ & $370 \cdot 0$ \\
\hline & Maize starch & $127 \cdot 8$ & $265 \cdot 3$ & $386 \cdot 0$ & $473 \cdot 0$ \\
\hline 1600 & Maize starch & $139 \cdot 0$ & $316 \cdot 0$ & $474 \cdot 0$ & $608 \cdot 0$ \\
\hline
\end{tabular}

* Calculated from cumulated amounts of reducing sugars appearing in the portal blood (Table 2) and variations in percentage of true glucose in reducing sugars.

$\uparrow$ Period (h) after the meal.

equations, glucose was the most efficiently absorbed (76-79\% for $400-800 \mathrm{~g}$ levels of intake) followed by products from the hydrolysis of sucrose $(61-62 \%)$ and maize starch $(60-54 \%)$, the differences increasing when the level of intake increased. The case of lactose must be underlined, since the amount of hydrolysis products appearing in the portal blood was the same at levels of intake of 400 and $800 \mathrm{~g}$, the coefficient of absorption thus decreasing from 34 to $16 \%$.

Nature of the hydrolysis products appearing in the blood circulation. The percentage of true glucose among the total reducing sugars varied according to the carbohydrate digested. Thus, the mean values were 85.6 (SEM $2 \cdot 8$ ) and $86 \cdot 1$ (SEM 0.7 ) \% with glucose and maize starch respectively, the total reducing substances probably including other reducing substances such as urea. In the case of lactose, the percentage of glucose was lower (64-65, SEM 4.4) but higher than expected from the chemical composition of this component. For sucrose, the percentage of glucose (52.3 (SEM 1.3)-56.3 (SEM 3.2)) was higher than expected; conversely, the percentage of fructose (31-36) was lower than expected since it constituted half the molecule of sucrose.

The amounts of glucose absorbed are given in Table 5. For lactose, these amounts were very low compared with those ingested, whatever the level of intake. They were substantially higher for sucrose and maize starch, but the high value of the latter was more marked when the level of ingestion was high. The results for glucose were the highest relative to the amounts ingested.

Appearance of lactic acid during digestion. There was no relationship between the level of intake of the four carbohydrates and the quantities of lactic acid appearing in the portal vein during the $8 \mathrm{~h}$ post-prandial period. Thus the mean amounts of lactic acid appearing in the portal circulation during digestion was calculated for each carbohydrate (Table 6). The amounts were rather large (no statistical difference between carbohydrates) and appeared very early in the portal blood. 
Table 6. Variations with time in the amounts of lactic acid appearing in the animal during digestion

(Mean values with their standard errors)

\begin{tabular}{|c|c|c|c|c|c|c|c|c|c|c|c|c|}
\hline \multirow[b]{3}{*}{ Carbohydrates } & \multirow[b]{3}{*}{$N$} & \multirow[b]{3}{*}{$A$} & \multirow{2}{*}{\multicolumn{2}{|c|}{$\begin{array}{c}\text { Fresh wt } \\
\text { intake }(\mathrm{g})^{*}\end{array}$}} & \multicolumn{8}{|c|}{$\begin{array}{c}\text { Amount of lactic acid (g) appearing } \\
\text { in the portal vein }\end{array}$} \\
\hline & & & & & \multicolumn{2}{|c|}{$2 \dagger$} & \multicolumn{2}{|c|}{$4 \uparrow$} & \multicolumn{2}{|c|}{$6 \dagger$} & \multicolumn{2}{|c|}{$8+$} \\
\hline & & & Mean & SEM & Mean & SEM & Mean & SEM & Mean & SEM & Mean & SEM \\
\hline Glucose & 13 & 10 & 619 & 68 & $6 \cdot 7$ & $1 \cdot 0$ & $14 \cdot 1$ & $2 \cdot 1$ & $19 \cdot 8$ & $3 \cdot 0$ & $22 \cdot 6$ & $3 \cdot 4$ \\
\hline Sucrose & 6 & 5 & 542 & 93 & $8 \cdot 8$ & $1 \cdot 6$ & 14.8 & 1.9 & $19 \cdot 8$ & $2 \cdot 3$ & $23 \cdot 4$ & $3 \cdot 2$ \\
\hline Maize starch & 15 & 11 & 825 & 123 & $7 \cdot 1$ & 0.6 & $14 \cdot 9$ & $1 \cdot 3$ & $22 \cdot 1$ & $2 \cdot 0$ & $28 \cdot 3$ & $2 \cdot 7$ \\
\hline Lactose & 8 & 6 & 691 & 67 & $4 \cdot 3$ & 0.6 & $10 \cdot 1$ & $1 \cdot 5$ & $15 \cdot 6$ & $2 \cdot 4$ & $20 \cdot 0$ & $3 \cdot 1$ \\
\hline
\end{tabular}

$N$, no. of experimental meals; $A$, no. of animals.

* Whole diet (protein concentrate included).

$\dagger$ Period (h) after the meal.

\section{DISCUSSION}

Methodology

Porto-systemic differences coupled with portal blood flow-rate have been very seldom used in nutrient absorption studies. The only previous studies using an electromagnetic flow-meter on the portal vein have been performed by Rérat et al. (1980) in the pig and by Elwyn et al. (1968) in the dog. The significance and limits of this methodology have already been discussed (Rérat et al. 1980). With regard to the principle of this method, it should be emphasized that the absorption of all nutrients taking the lymphatic route cannot be analysed; these nutrients are generally long-chain fatty acids (Raulin et al. 1966) or protein fractions synthesized in the cell wall (Aliev, 1970). In addition, during its passage in the intestinal cell wall, the arterial blood may be depleted in nutrients taken up by the cells or be enriched in nutrients absorbed by the gut wall (a proportion may also be taken up by the cell wall during the transport). Consequently, the porto-arterial differences do not really account for the total appearance of all nutrients in the body, but only the net appearance of the fraction of these nutrients available for the organism (except the gut) (Rérat et al. 1980).

\section{Quantitative aspects of absorption}

Quantitative absorption kinetics. The quantitative kinetics of appearance of sugars in the portal vein confirms the variability in the time of appearance and length of digestion of carbohydrates according to their nature and level of intake whether average gross values (amounts absorbed $/ \mathrm{h}$ ) or processed values (regression of absorbed quantities on ingested quantities) are used.

Net absorption follows the same trends as for portal-arterial concentration differences because blood flow patterns did not differ significantly between meals. At low ingestion levels $(<400 \mathrm{~g})$ the rate of appearance of reducing sugars in the portal vein, the quantities absorbed $/ h$ and the length of time of digestion (i.e. transit and, when necessary, hydrolysis) are approximately the same for glucose, sucrose and maize starch, the digestion length of maize starch being much more variable. An increase in the ingestion level up to $800 \mathrm{~g}$ leads to an early differentiation of the behaviour of each sugar. The kinetics of appearance of glucose and of sucrose hydrolysis products in the portal blood then become quite different, and their appearance rate exceeds that of sugars resulting from maize starch hydrolysis. 
The sucrose-maize starch difference is also evident at the $1200 \mathrm{~g}$ level of intake. The different absorption of sugars resulting from glucose and from sucrose intake may be explained by the fact that sucrose must be hydrolysed by sucrase (EC 3.2.1.48) present in the brush border. In those conditions, there may be a delay which is not too long since the hydrolysis and the transport are almost simultaneous. The differences between glucose and sucrose on the one hand and maize starch, on the other, may be explained either by a decreased rate of emptying of maize starch or by a decreased rate of intestinal hydrolysis. In other words, the late and prolonged appearance of reducing sugars after intake of maize starch may either be due to gastric emptying rate or intestinal enzymic hydrolysis rate. However, the first hypothesis is not valid since the amounts of starch entering the duodenum from the stomach during the first hours of digestion always largely exceed the amounts of hydrolysis products absorbed at the same time. This is shown by comparing our own absorption values with the gastric emptying values obtained by duodenal sampling (Cuber et al. 1980) after ingestion of an $800 \mathrm{~g}$ starch meal. However, it appears that a total replacement of starch by glucose or sucrose reduces the gastric emptying rate (Auffray et al. 1967; Ly, 1975). It may therefore be assumed that the limiting factor of glucose absorption after ingestion of maize starch is not related to the gastric emptying rate since large amounts of maize starch are found in the small intestine immediately after the meal and since, in spite of that, the absorption is slower than that of sugars such as sucrose and glucose which are theoretically emptied more slowly.

Thus, the limiting factor of glucose appearance in the portal blood after ingestion of maize starch seems to be the enzymic hydrolysis rate. The mean amount of $\alpha$-amylase (EC 3.2.1.1) units secreted by a $50 \mathrm{~kg}$ pig is 1.7 million during each of the first two $0.5 \mathrm{~h}$ periods after the meal and 2.8 million/h during the following period (T. Corring, personal communication; 1 unit of $\alpha$-amylase activity is defined as the amount causing hydrolysis of $1.0 \mathrm{mg}$ soluble starch (Merck) over $30 \mathrm{~min}$ at $37^{\circ}$ ). Thus, the pig is able to break down $1700 \mathrm{~g}$ starch during each of the first $2 \mathrm{~h}$, then $2800 \mathrm{~g}$ during each of the successive hours if the $\alpha$-amylase initially used and released after the hydrolysis does not act in addition to that secreted during subsequent periods. According it does not seem that the amount of secreted $\alpha$-amylase represents the limiting factor of digestion expressed in terms of absorption of maize-starch-hydrolysis products. On the other hand, the hydrolysis conditions do seem to be involved according to studies on the variation in the duodenal $\mathrm{pH}$, made by T. Corring and $\mathbf{J}$. P. Laplace (unpublished results): a rather acid $\mathrm{pH}$ seems to persist within the mass of starch in the small intestine and this would represent the limiting factor for hydrolysis since the latter requires a rather basic $\mathrm{pH}$.

Lactose differs from the other sugars not only in a lower level of appearance of its hydrolysis products in the portal vein but also because this level is not modified by variations in the intake. It appears that the amounts of lactase (EC 3.2.1.23) can break down only a given quantity of lactose when the degradation is not preceded by a period of adaptation. The limiting factor therefore seems to be the hydrolysis rate since the gastric emptying does not seem to undergo any changes, even if the electric potentials of the digestive cell wall are highly disturbed by the ingestion of lactose in an animal unaccustomed to that type of carbohydrate (Laplace, 1978). However, it could be that lactose is absorbed as such (Fischer et al. 1965) and that a fraction is not included in the measurement of reducing sugars thus reducing the absorption results concerning that sugar.

Balance of sugar absorption and quantitative aspects of the gut wall metabolism of carbohydrates. It was emphasized (Rérat et al. 1984) that, because of the rather short observation period after the meal $(8 \mathrm{~h})$, it was impossible to draw up absorption balances, especially for slowly-digested carbohydrates. However, in some animals, given small amounts of glucose and sucrose, the porto-arterial differences disappeared before the end 
of the post-prandial $8 \mathrm{~h}$ period. At higher levels of intake and during longer observation periods the disappearance of these differences was also noted (Table 4). It may therefore be assumed that digestion is finished and that an over-all absorption balance can be made up. On average $14 \mathrm{~g}$ reducing sugars/ $\mathrm{h}$ were not recovered in the portal vein within $8 \mathrm{~h}$ after intake of a meal including $400 \mathrm{~g}$, or less, glucose; the mean values for the same mean level of intake of sucrose were $24 \mathrm{~g} / \mathrm{h}$. Several hypotheses may be put forward: (1) a fraction of the sugars absorbed may have used the lymphatic route. This hypothesis, however, not only contradicts present knowledge but the fact that the amount absorbed in such a way could only be small since the lymphatic flow-rate is very low relative to the portal flow-rate (Dawson \& Porter, 1962); (2) a fraction of the carbohydrates ingested may be metabolized in the intestinal lumen by the microflora and appear in the portal vein in a form not measured in the present experiments. It has been well established that a fairly large fraction of the sugars consumed arrives intact in the large bowel where a variable amount of volatile fatty acids of different kinds are produced, depending on the volume of this fraction which has not been digested in the small bowel (Etienne, 1969). For glucose there was no evidence of this undigested fraction while, for sucrose, it ranged between 1 and $6 \%$ (Cunningham et al. 1963) and for maize starch between 4 and 7\% (Keys \& de Barthe 1974). The amounts of reducing sugars not included in the absorption balance should be corrected in order to take into account these ileal digestibilities resulting in 14-21 g/h. The lowest estimates correspond approximately to the quantities lacking after intake of $1200 \mathrm{~g}$ wheat (i.e. $220 \mathrm{~g}$ in $22 \mathrm{~h}$ ) during $24 \mathrm{~h}$ observations (Rérat, 1981); (3) it may thus be assumed that the fraction not recovered in the large intestine or in the portal blood has been taken up and metabolized during its transfer by the enterocyte and appears in the portal vein in the form of metabolites. A part of these nutrients is recovered in the form of lactic acid, the quantities produced in $8 \mathrm{~h}(20-28 \mathrm{~g})$ representing, however, only $15-25 \%$ of the sugars not included in the absorption balance. This formation of lactic acid is in agreement with the findings of Windmueller \& Spaeth (1978) who indicated that other metabolites such as carbon dioxide and alanine may be formed. Indeed, the amounts of glycine and alanine appearing in the pig portal vein after intake of cereals (Rérat et al. 1979b) greatly exceed those ingested. Moreover, the amounts of ammonia-nitrogen absorbed during digestion are much lower than the urea- $\mathrm{N}$ secreted in the intestine in the same time (Rérat et al. 1979a). This might account for a re-utilization of $\mathrm{NH}_{3}-\mathrm{N}$ in the gut wall resulting in formation of alanine at the expense of glucose. To verify these hypotheses it would be necessary to make up total metabolic balances of all metabolites in the intestine.

Qualitative aspects of the gut wall metabolism of carbohydrates. The percentage of glucose present in the reducing sugars gives information about the transport and metabolism of hexoses in the intestinal cell wall. These values should reach $100 \%$ in the case of absorption of glucose- or maize-starch-hydrolysis products, but they only reach $85-90 \%$. As already pointed out, this difference depends on the technique used to measure the reducing sugars which takes into account other reducing substances such as urea (Rérat et al. 1984). In the case of lactose- and sucrose-hydrolysis products (half the molecules of which are glucose and galactose or fructose) the percentage of glucose in the reducing sugars should not exceed 43-45, taking into account the correction factor due to other reducing substances. The percentage of glucose, however, is about 65 in the case of lactose, representing an excess of $44 \%$ glucose in the mixture of reducing sugars appearing in the portal vein. Two hypotheses may explain this excess. (1) It may be due to a faster absorption of glucose. Indeed, it has been well established in man that the jejunal absorption rate of galactose is slower than that of glucose when both hexoses are present simultaneously in the liquid ingested (Haworth et al. 1965). These facts may be explained by the existence of a common carrier for the two hexoses (Jorgensen et al. 1960), but in those circumstances it is difficult 
to understand why the presence of galactose does not inhibit the absorption of glucose when the contrary seems to be the case. (2) A second hypothesis is the metabolism of galactose to glucose. This hypothesis could be valid since the gut wall of the rat (Koo et al. 1975) contains all the enzymes of Leloir's reaction, responsible for the conversion of galactose into glucose, glycogen or structural polysaccharides, and since in vitro active metabolism of galactose has been observed (Berman et al. 1976). This hypothesis is confirmed by the fact that $8 \mathrm{~h}$ after a meal $(400 \mathrm{~g})$ of hydrolysed lactose, the percentage net absorption of glucose was 114 and that of galactose 52 (Rérat, 1983).

For sucrose, the percentage of glucose present in the reducing sugars of the portal blood was also too high, especially during the first hours: more than $25 \%$ fructose was missing during the first $2 \mathrm{~h}$ and $17 \%$ during the $8 \mathrm{~h}$ of post-prandial observation. The same hypothesis as that for galactose may be put forward. With regard to the transport of carbohydrates, it has been well established that fructose is absorbed more slowly than glucose (Gray \& Ingelfinger, 1966); however, in man, fructose appears as quickly as glucose in the portal vein (Dencker et al. 1972). Furthermore, it was shown in vivo that a conversion of fructose into glucose takes place during the absorption which is much greater in the hamster than in the rat (Kiyasu \& Chaikoff, 1957; Mavrias \& Mayer, 1973). According to the results of the present experiment, the pig seems to be located between the rat and the hamster, with a partial transformation of fructose into glucose, but this is not in agreement with the findings of Aherne et al. (1969) who showed in vivo a very small appearance of glucose in the blood after injection of fructose into an intestinal loop. Neither does it agree with the findings of Talafantova \& Kolinska (1977) who showed in vitro that only a very small amount of fructose is transformed into glucose in the intestinal cell. These discrepancies may be explained by the different age of the animals used by these two groups of workers (very young) and ours (3-4 months old), as the metabolic capacities of the intestinal cell seem to develop with age (Talafantova \& Kolinska, 1977).

In the pig, our experiments show that a proportion of the absorbed hexoses is also metabolized in the form of lactic acid. The possibility of such a metabolic activity is known in other species. Thus, Kiyasu \& Chaikoff (1957) report a larger in vivo formation in the rat of lactate with fructose than with glucose. Our results obtained in the pig do not provide evidence for any significant differences in the formation of lactic acid for the different carbohydrates ingested. It should also be pointed out that a proportion of the lactic acid formed may originate from the activity of the intestinal microflora which probably varies according to the nature of the carbohydrate. The very early appearance of lactic acid in the portal blood seems to be more in favour of the metabolic activity in the gut wall, although it is known that rather large amounts of lactic acid may be formed in the gastric contents after ingestion of starch in the pig (Etienne, 1969; Cranwell et al. 1976).

In conclusion, the transit, enzymic hydrolysis and absorption of the various carbohydrates lead to the appearance of variable amounts of sugars in the portal vein according to the nature and quantity of the carbohydrates ingested. In the case of glucose, sucrose and maize starch, the amounts which appear in the portal vein are proportional to those ingested, but the amounts of lactose-hydrolysis products absorbed do not change for $8 \mathrm{~h}$ after the meal whatever the quantity ingested. The amounts of sugars appearing in the portal vein during a post-prandial period of $8 \mathrm{~h}$ are the highest after intake of glucose and sucrose, much lower after intake of maize starch and low after intake of lactose. Part of the absorbed sugars is metabolized in the intestine cell wall leading to some transformation of galactose and fructose into glucose, to a rather large uptake of sugars $(14-21 \mathrm{~g} / \mathrm{h})$ and to the formation of lactic acid $(2 \cdot 5-3 \cdot 5 \mathrm{~g} / \mathrm{h})$.

The phenomena pointed out by these experiments show several interesting nutritional aspects. (1) The supply of energy is not the same chronologically when one sugar is replaced 
by another even for an unchanged dietary energy content. (2) What influence, however, do such variations have on the utilization of carbohydrates and proteins by the tissues? (3) The slow digestion of some carbohydrates, such as maize starch, leads to a continuous supply of energy to the animal between one meal and the next. However, in the case of some carbohydrates, such as lactose, slow digestion may favour the arrival of fermentable substrates in the large intestine leading to formation of either useful or noxious substances. (4) The uptake of carbohydrate nutrients by the gastrointestinal cell wall shows the high metabolic function of this tissue.

Acknowledgement is given to Mrs K. Rérat for the English translation of the manuscript.

\section{REFERENCES}

Aherne, F., Hays, V. W., Ewan, R. C. \& Speer, V. C. (1969). Journal of Animal Science 29, 444450.

Aliev, A. A. (1970). Sel'sko-khozyaistvennaya. Biologiya, Moscou 5, 369-401.

Auffray, P., Martinet, J. \& Rérat, A. (1967). Annales de Biologie Animale, Biochimie, Biophysique 7, $261-279$.

Berman, W. F., Bautista, J. O., Rogers, S. \& Segal, S. (1976). Biochimica et Biophysica Acta 455, 90-101.

Cranwell, P. D., Noakes, D. E. \& Hill, K. J. (1976). British Journal of Nutrition 36, 71-86.

Cuber, J. C., Laplace, J. P. \& Villiers, P. A. (1980). Reproduction, Nutrition, Développement 20(4B), 1161-1172.

Cunningham, H. M., Friend, D. W. \& Nicholson, J. W. G. (1963). Canadian Journal of Animal Science 43, $215-225$.

Dawson, R. \& Porter, J. W. G. (1962). British Journal of Nutrition 16, 27-38.

Dencker, H., Lunderquist, A., Meeuwisse, G., Norryd, C. \& Tranberg, K. G. (1972). Gastroenterology 7, 701-705.

Elwyn, D. H., Parikh, H. C. \& Shoemaker, W. C. (1968). American Journal of Physiology 215, $1260-1275$.

Etienne, M. (1969). Journées de la Recherche Porcine en France, vol, 1, pp. 131-136. Paris: Institut National de la Recherche Agronomique, Institut Technique du Porc.

Fischer, R. A., Rosoff, B. M., Altshuler, J. G., Thayer, W. R. \& Spiro, H. M. (1965). Cancer $18,1278$.

Gray, G. M. \& Ingelfinger, F. J. (1966). Journal of Clinical Investigation 45, 388-398.

Haworth, J. C., Ford, J. D. \& Robinson, T. J. (1965). Clinical Science 29, 83-92.

Jorgensen, C. R., Landau, B. R. \& Wilson, T. H. (1960). Federation Proceedings 19, 130 Abstr.

Keys, J. E. \& de Barthe, J. V. (1974). Journal of Animal Science 39, 57-62.

Kiyasu, J. Y. \& Chaikoff, I. L. (1957). Journal of Biological Chemistry 224, 935-939.

Koo, C., Rogers, S. \& Segal, S. (1975). Biology of the Neonate 27, 153-162.

Laplace, J. P. (1978). Annales de Zootechnie 27, 495-517.

Ly, J. (1975). Cuban Journal of Agricultural Science 9, 291-298.

Mavrias, D. A. \& Mayer, R. J. (1973). Biochimica et Biophysica Acta 291, 531-537.

Raulin, J., Loriette, C., Flanzy, J. \& Rérat, A. (1966). Biochimica et Biophysica Acta 116, 385-388.

Rérat, A. (1971). Annales de Biologie Animale, Biochimie, Biophysique 11, 277.

Rérat, A. (1981). Bulletin de I Académie Nationale de Médecine 8, 59-65.

Rérat, A. (1983). Bulletin de P Académie Nationale de Médecine 14, 297-302.

Rérat, A., Lisoprawski, C., Vaissade, P. \& Vaugelade, P. (1979a). Bulletin de I Académie Vétérinaire de France 52, 333-346.

Rérat, A., Vaissade, P. \& Vaugelade, P. (1979b). Annales de Biologie Animale, Biochimie, Biophysique 19, $739-747$.

Rérat, A., Vaissade, P. \& Vaugelade, P. (1984). British Journal of Nutrition 51, 505-515.

Rérat, A., Vaugelade, P. \& Villiers, P. A. (1980). In Current Concepts of Digestion and Absorption in Pigs. Technical Bulletin no. 3, pp. 177-214, [A. G. Low and I. G. Partridge, editors]. Reading and Ayr: National Institute for Research in Dairying and Hannah Research Institute.

Snedecor, G. W. \& Cochran, W. G. (1967). Statistical Methods, pp. 593. Ames, lowa: Iowa State University Press. Talafantova, M. \& Kolinska, J. (1977). Folia Biologica Czechoslovakia 23, 76-80.

Windmueller, H. G. \& Spaeth, A. E. (1978). Journal of Biological Chemistry 253, 69-76. 